\title{
Intrahepatic Cholangiocarcinoma: Evolving Concepts and Medical Treatment
}

\author{
Hong Ja Kim \\ Division of Gastroenterology, Department of Internal Medicine, Dankook University College of Medicine, Cheonan, Korea
}

Cholangiocarcinoma (bile duct cancer) is classified into intrahepatic and extrahepatic cholangiocarcinoma (perihilar and distal cholangiocarcinoma) according to the anatomical location of the lesion. The incidence of extrahepatic cholangiocarcinoma has been relatively stagnant in recent decades, but intrahepatic cholangiocarcinoma is steadily increasing worldwide, requiring attention. Various classification systems based on gross growth patterns, histological findings, and tumor-derived cells, as well as classification based on existing anatomical location, have been proposed, however, the consensus has not been established yet. Intrahepatic cholangiocarcinoma is a carcinoma with an extremely poor prognosis. Complete tumor resection is the only curative treatment. The overall survival rate for 5 years after surgery is $15 \%$ to $40 \%$, but recurrence after surgery is observed in $2 / 3$ patients. Therefore, determining the right stage before surgery and selecting an appropriate treatment method through a multidisciplinary approach is a very important process in determining proper treatment. Systemic therapy may be used for locally advanced biliary tract cancer or metastatic biliary tract cancer where surgery is not possible. However, the effectiveness of traditional anticancer chemotherapeutic agents is rather pessimistic, therefore treatments using molecular biological properties have recently been attempted. Finding a way to increase the number of resectable cases through early diagnosis is one of the main challenges. In addition, it is also hoped that the selection of new therapeutic targets and therapeutics will be possible as a result of advanced research on gene expression profiles and mutations in cholangiocarcinoma.

Korean J Pancreas Biliary Tract 2021;26(1):33-42

Keywords: Intrahepatic cholangiocarcinoma, Classification, Staging, Medical treatment
Received Apr. 29, 2020

Revised Jul. 20, 2020

Accepted Sep. 3, 2020

Corresponding author : Hong Ja Kim

Division of Gastroenterology, Department of Internal Medicine, Dankook University College of Medicine, 119 Dandae-ro, Dongnam-gu, Cheonan 31116, Korea Tel: +82-41-550-3917

Fax. $+82-41-556-0524$

E-mail: hjkimjung@hotmail.com

ORCID: https://orcid.org/0000-0003-1781-4126

This is an Open Access article distributed under the terms of the Creative Commons Attribution Non-Commercial License (http:// creativecommons.org/licenses/by-nc/3.0/) which permits unrestricted non-commercial use, distribution, and reproduction in any medium, provided the original work is properly cited.

Copyright $\odot 2021$ by The Korean Journal of Pancreas and Biliary Tract

\section{서 론}

담관암은 해부학적 위치에 따라 간내담관, 간외담관, 담낭을 포함하는 다양한 담관 상피에서 발생하는 종양이다. ${ }^{1}$ 전
세계적으로 모든 성인 악성 종양의 $0.7 \%$ 와 모든 위장 악성 종양의 $3 \%$ 를 차지하여 발생 빈도는 높지 않다. 그러나 초기 증상이 없는 경우가 흔하여 많은 경우 진단 당시 전이된 상태로 발견되어 적절한 치료가 어렵고 사망률이 높은 암이다. ${ }^{2}$ 
세계적으로 10 만 명 당 연간 2 명의 발생 빈도를 보이나 지역적 편차가 커 태국 등의 일부 아시아 국가에서는 이보다 40 배 이상의 높은 발생 빈도를 보여 10 만 명 당 연간 96 명의 발생 빈도를 보고한 적도 있다. ${ }^{3,4} 2017$ 년까지의 자료를 바탕으로 2019년 보건복지부 중앙암등록본부(www.cancer.go.kr)에서 발표한 자료에 따르면 담관암은 2017년 한국에서 전체 암의 $2.9 \%$ 로 9 위를 차지하였다. 10 만 명 당 연간 13.4 명이 발생하였으며, 2015-2017년까지 감소하지는 않고 있어 국가적 관심 및 대응이 필요하다.

담관암은 병변의 해부학적 위치에 따라 간내 담관암과 간외 담관암(간문주변부 담관암과 원위부 담관암)으로 분류한다. ${ }^{1}$ 간내 담관암은 담관암 중 특히 간내담관에서 발생하는 암으로 정의되며 전체 담관암의 5-20\%를 차지하며 간에 발생한 원발성 악성 종양 중 간세포암(hepatocelluar carcinoma, HCC) 다음으로 흔히 발생한다. 담관암 내에서도 간외 담관암은 최근 수십 년간 발생 빈도가 비교적 정체상태에 있으나 간내 담관암은 세계적으로 꾸준히 증가하고 있다. ${ }^{5,6}$

본 종설은 담관암 중 특히 간내 담관암의 역학, 분류체계, 병기 결정 등에 관한 최신 지견을 살펴보고, 간내 담관암의 치료 중 특히 수술이 불가능한 국소진행형 담관암 및 전이성 담관암의 최근의 치료방법에 대해 살펴보고자 한다.

\section{본 론}

\section{1. 역학}

담관암의 발생률은 지난 40 년 동안 전 세계적으로 증가하고 있다. ${ }^{5,6}$ 담관암을 간내 담관암 및 간외 담관암으로 분류할 경우 유럽, 북미, 아시아, 일본 및 호주에서 특히 간내 담관암의 발생률이 최근 20 년 동안 증가하고 있지만 간외 담관암의 발생률은 국제적으로 감소하고 있다. ${ }^{2,7-9}$ 물론 이런 추세를 보이는 이유가 국제질병분류(International Classification of Disease) 코드 체계의 변화와 연관이 있을 것으로 추정된다. 즉, 과거 간외 담관암의 한 종류인 Klatskin 종양에 고유한 질병코드를 할당하였으나 변경된 국제질병분류 코드체계 에서는 Klatskin 종양의 고유 코드가 삭제되어 기존의 Klatskin 종양이 간외 담관암 또는 간내 담관암으로 대체되어 분류됨으로써 상대적으로 간내 담관암이 증가한 것처럼 보일 수 있다. ${ }^{5,10}$
그러나 분류의 기술적 문제 외에도 최근 관찰되는 비만율 증가 및 만성 바이러스성 간염의 변화 등 담관암종의 실제 발생률에 영향을 줄 수 있는 몇 가지 인구통계학적 경향을 무시할 수 없으며, 일부는 과거 진단 불가능 하였던 담관 악성 종양을 식별하는 새로운 진단 도구의 정확성 및 가용성 개선 등 진단 방법의 발전에 기인할 수 있다. ${ }^{11}$

담관암은 명백한 원인 없이 발생하기도 하지만 만성적인 담도 염증 및 이로 인한 담도상피세포의 과형성-이형성-악성화 사이클은 잘 알려진 담관암의 병인이다. 원발성 경화성 담관염(primary sclerosing cholangitis)과 선천성 담관 낭종, 간내 결석, 간내 담도의 기생충 감염 등은 이를 잘 증명하는 담관암의 위험인자이다. ${ }^{12-15}$ 비 담도성 간질환으로 간경변, 만성 바이러스성 간염(B형간염, $\mathrm{C}$ 형간염)도 담관암의 위험인자로 알려져 있으며 이들은 특히 담관암 중 간내 담관암의 발생과 밀접하게 관련되어 있을 것으로 추정된다. ${ }^{16,17}$ 비만 관련 간질환이나 알콜성 간질환과 같은 비 바이러스성 만성 간질환도 $\mathrm{HCC}$ 와 마찬가지로 간내 담관암과 관련이 있는 것으로 추정되며 사례-대조 연구를 통해 비 특이성 간경변증(adjusted odd ratio [OR] 27.2)과 알코올성 간질환(adjusted OR 7.4)은 간내 담관암의 위험인자임을 보고한 Shaib 등 ${ }^{18}$ 의 연구나, 평균 6년 동안 원인과 관계없이 모든 간경변증 환자 11,605 명을 대상으로 하여 간경변증 환자에서 일반인에 비해 간내 담관암 발생률이 10 배 더 높음을 보여준 덴마크 코호트 연구 등이 이를 뒷받침한다. ${ }^{19}$ 비만 및 동반된 대사증후군의 증가도 간내 담관암의 위험 증가와 관련이 있을 것으로 보고된다. ${ }^{20-22}$ 1996-2013년까지 발표된 문헌을 검색 후 적절한 10 개의 연구를 메타분석한 $\mathrm{Li}$ 등 ${ }^{21}$ 의 연구에서 이들은 정상 체중, 과체중, 비만 및 초과 체중을 체질량지수(body mass index)가 각각 18.5-24.9, $25-29.9, \geq 30$ 및 $\geq 25 \mathrm{~kg} / \mathrm{m}^{2}$ 로 정의하였을 때 과체중 $(\mathrm{OR} 1.30$, 95\% CI 1.13-1.49), 비만(OR 1.52, 95\% CI 1.13-1.89) 및 초과 체중(OR $1.37,95 \% \mathrm{CI} 1.22-1.55)$ 이 담관암과 유의한 관련이 있음을 보고하였다. 또한 13 개의 미국 기반 전향적 코호트 연구 컨소시엄인 간암 풀링 프로젝트의 데이터와 이전까지 발표된 코호트 연구의 데이터를 합쳐 메타분석 결과 ${ }^{22}$ 비만에서 간내 담관암의 위험이 $49 \%$ 증가한 것으로 나타났으며 $(\mathrm{RR}=1.49$, 95\% CI 1.32-1.70), 당뇨병은 53\% 증가된 간내 담관암 발생 위험과 관련이 있다(RR=1.51.5, 95\% CI 1.31-1.78)는 보고도 있다. 그러나 비만 및 대사증후군과 간내 담관암 발생에 관해서는 향후 좀 더 체계적인 연구가 필요하다. 


\section{2. 담관암의 분류}

다양한 분야에서 발표되고 있는 담관암 연구를 바탕으로 담관암은 기존의 해부학적 위치에 의한 분류뿐 아니라, 육안적 성장 패턴, 조직학적 소견, 종양이 기원한 세포 등을 기준으로 하는 다양한 분류체계가 제시되고 있으나 아직 합의된 의견이 정립되지 않은 상태이다. 그러나 이러한 분류의 이해는 담관암의 생물학적 특성을 이해함으로써, 이를 이용한 최적의 치료 방법 선택 및 환자의 예후 예측 등에 적용 가능하여 임상의에게 도움이 된다. ${ }^{23,24}$

\section{1) 해부학적 위치 및 육안적 성장 패턴에 따른 분류}

고전적으로 해부학적 위치(Fig. 1)에 기초하여 담관암은 간내 담관암(intrahepatic cholangiocarcinoma), 간문주변부 담관암(perihilar cholangiocarcinoma), 원위부 담관암(distal cholangiocarcinoma)으로 분류된다. ${ }^{1}$ 해부학적으로 간내 담관암은 2 차 간내 담관의 외연부에 위치한 담도로부터 발생한 악성 종양으로 정의된다. Klatskin tumor로 흔히 불리는 간문주변부 담관암은 일반적으로 담낭관 합류부의 근위부에 해당하는 간외 담관을 침 범한 종양을 의미한다. 하지만 개개인에 따라 담낭관의 담관 합류 위치의 차이가 있을 수 있고 합류부의 해부학적 변형이 많아 간내 담관과 간외 담관 경계가 명확하지 않고, 또한 간문주변부 담관암이라도 상당한 정도의 간내 담관의 침범을 동반할 수 있어 간문주변부의 정의에 혼란이 있을 수 있다. 원위부 담관암은 담낭관 합류부 하방 총담관에서 발생한 암을 정의한다.

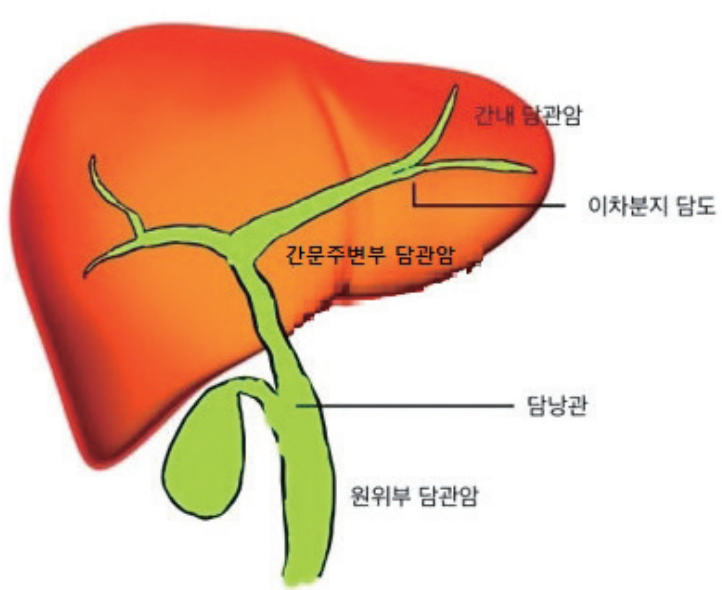

Fig. 1. Classifications of cholangiocarcinoma according to the anatomical location.
육안적 성장 패턴에 따라 담관암의 병리학적 성질뿐 아니라 임상 양상도 상이함이 보고되어 종양의 성장 양상은 중요한 임상적 단서를 제공한다. 성장 패턴에 따른 다양한 분류체계가 제시되고 있으며, 간내 담관암의 경우 육안적 성장 양상에 따라 종괴형(mass forming), 담관 주위 침윤형(periductal infiltrating), 담관 내 성장형(intraductal growing)의 세 가지 패턴으로 분류한 일본 간암연구회의 분류를 흔히 사용한다(Fig. 2). ${ }^{25,26}$ 두 가지 이상의 육안적 성장 형태가 함께 보이는 경우 혼합형으로 분류하며 종괴형 + 담관 주위 침윤형 등으로 표기한다. 종괴형은 간내 담관암의 가장 일반적인 성장 패턴으로, 모든 간내 담관암의 약 $65 \%$ 를 차지한다. 간내 담관암은 $\mathrm{HCC}$ 와 달리 정상적인 간에서도 흔히 발생하지만 종괴형의 일부는 만성 바이러스성 간염 등과 같은 비 담도성 만성 간질환이 동반된 간의 작은 간내담관(small intrahepatic bile duct)에서 호발한다. 이와 대조적으로 담관 주위 침윤형이나 담관 내 성장형은 만성 담도 질환이 동반된 간에서 호발하며 큰 간내담관의 분포영역에서 대부분 발생한다. 종괴형은 주로 담관벽 주위로 성장하여 종괴를 형성하며 종괴의 중심 괴사(central necrosis)와 반흔(scaring)이 흔히 관찰된다. 담관 주위 침윤형이나 담관 내 성장형은 종양이 주로 담도벽의 종축을 따라 성장하는 데 종축 성장 시 담도의 점막표면을 통한 전파보다 점막하부 침윤을 통한 전파가 흔하다. 담관 주위 침윤형은 횡축으로도 성장하여 인접한 신경, 혈관 등으로 종양 침범하며 이는 영상 검사에서 특징적인 담도벽 비후 및 협착 소견으로 관찰된다. 담관 내로 폴리포이드 또는 유두 모양의 종괴가 성장하는 담관 내 성장형은 $4 \%$ 정도를 차지하며 담관 주위 침윤형과 달리 횡축 성장은 드물고 주로 점막을 따른 종축 성장을 하여 담관 내에 국한된 성장을 보이는 경우가 많아 종괴형이나 담관 주위
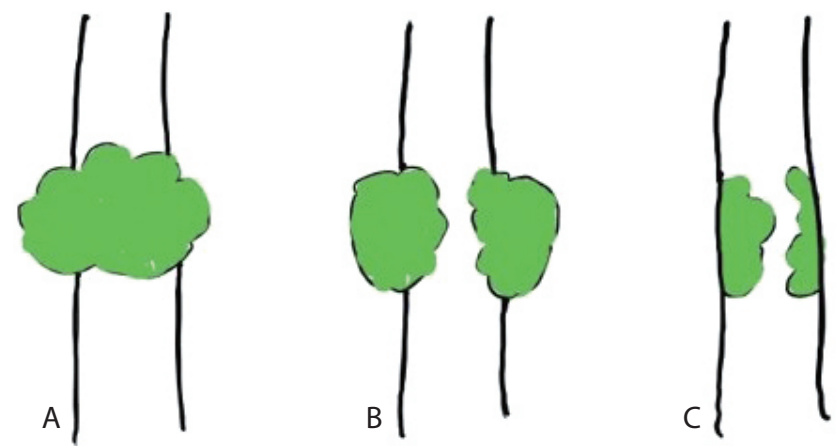

Fig. 2. Classifications of intrahepatic cholangiocarcinoma according to the growth pattern. (A) Mass-forming. (B) Periductal infiltrating. (C) Intraductal growing. 
침윤형에 비해 예후가 좋다. ${ }^{2728}$

간문부 담관암이나 원위부 담관암은 간내 담관암의 담관 주위 침윤형과 유사한 육안적 성장 패턴 및 임상적 특징을 보인다. 즉, 큰 간내담관(large intrahepatic bile duct)에서 발생하여 담도를 따라 종축 및 방사상으로 성장하며 점진적으로 담도벽의 협착을 야기한다. 간내 담관암과 달리 주변 조직으로 침투성 성장과 결절형 성장이 혼합된 결절경화형(nodular sclerosing type) 성장 패턴이 $80 \%$ 이상을 차지하고 일부에서 담관 내 유두형 패턴의 성장(intraductal papillary type)을 보인다.

\section{2) 조직학적 분류}

대부분의 담관암은 조직학적으로 세포 내 점액이 풍부한 선암으로써 풍부한 결합조직기질(desmoplastic stroma) 및 염증반응의 동반이 특징적 소견이다. 그러나 해부학적 위치나 성장패턴과 무관하게 비교적 동일한 조직 소견을 보이는 간문부 담관암이나 원위부 담관암과 달리 간내 담관암은 해부학적 위치 및 육안 소견에 따라 담관암의 특징적 조직 소견과는 다른 다양한 조직 형태학적 스펙트럼을 보이며, 이러한 다양한 조직병리 소견에 따라 간내 담관암의 전암병변, 위험인자, 예후 등의 임상적 특징도 상이하여 간내 담관암 환자의 적절한 치료를 위해서는 체계적 조직학적 분류체계의 정립이 필요하다는 지적이 있어 왔다. ${ }^{29,30}$

Nakanuma 등 ${ }^{29}$ 은 간내 담관암을 조직 소견에서 관찰되는 담관의 크기에 따라 통상형 담관암, 미세 담도 기원의 담세관형 담관암, 담관 내암, 변형암 등으로 분류한 새로운 분류법을 제시하였다(Table 1). 이들은 특히 기존의 간내 담관암에 해당하는 통상형 간내 담관암을 세분하여 간내담도의 이차 분지 이내의 큰 간내담도(large bile duct)에서 발생하는 큰 담관형 (large bile duct type)과 이차 분지 이후 말초의 작은 간내담도(small bile duct)로부터 발생하는 작은 담관형 (small bile duct type)으로 분류하였다. 큰 담관형은 간외 담관암과 유사한 특징을 보여 점액이 풍부한 선암으로 구성되어 있어 간문부형 또는 점액형이라고도 명명하였다. 종괴형성형 성장뿐 아니라 침투형, 간내 성장형의 다양한 성장 패턴을 보이며, 간외 담관암의 전암병변으로 잘 알려진 담관 상피내 종양(biliary intraepithelial neoplasm)과 담관 내 유두상 종양(intraductal papillary neoplasm of bile duct)이 동반된 경우가 흔하고 원발성 경화성 담관염과 관련된 경우가 작은 담관형에 비해 많다. 이와 대조적으로 작은 담관형은 말초형 또는 혼합형이라고도 명명하며 종양세포의
점액생산이 거의 없으며 대부분이 종괴형성형 성장을 한다. 바이러스성 간염 또는 간경변등의 비 담도성 만성 간질환과 관련되어 있는 경우가 많으며, 담관 상피내 종양이나 담관 내 유두상 종양 등의 담관암 전암병변과 거의 관련이 없다. 흥미롭게도 작은 담관형은 CK-19 양성 $\mathrm{HCC}$ 와 유사한 임상병리학적 특징을 보인다. ${ }^{31} \mathrm{Liau}$ 등 ${ }^{30}$ 은 Nakanuma 등 ${ }^{29}$ 과 달리 큰 담관형을 담관형(bile duct type), 작은 담관형에 해당하는 종양을 담세관형(cholangioloar type)으로 명명하는 등 분류법에 다소 차이는 있으나 분류에 따른 임상적 특징은 비교적 동일하다.

\section{3) 기원세포(cells of origin) 및 암줄기세포(cancer stem cells)}

기원세포 또는 종양개시세포(cancer initiating cells)란 종양을 유발하는 돌연변이를 처음으로 획득한 정상 세포로 정의된다. 이와 달리 암줄기세포(cancer stem cells)란 종양의 성장과 전파를 지속시키는 종양 세포 중 특정 세포로 정의되며 자체 재생 및 타 세포군으로 전환 생산이 가능한 특징을 가지고 있다. ${ }^{32}$ 담관암 종양 발생 과정에서 기원세포나 암줄기세포의 역할에 대해서는 아직까지 밝혀지지 않은 부분이 많다. 그러나 담관암의 해부학적 위치에 따른 조직학적 특성이 다른 점을 고려한다면 간내 담관암과 간외 담관암의 기원세포나 암줄기 세포는 다를 것으로 추정되며, 간내 담관암 중에서도 작은

\section{Table 1. Proposed new classification of intrahepatic cholangiocarcinoma ${ }^{29}$}

Conventional type (bile duct type) adenocarcinoma
Small bile duct type (peripheral type)
Well differentiated
Well differentiated moderately differentiated
Moderately differentiated poorly differentiated
Poorly differentiated
Large bile duct type (perihilar type)
Well differentiated
Moderately differentiated
Poorly differentiated
Bile ductular type
Intraductal type
Papillary type
Tubular type
Superficial spreading type
Rare variants
Squamous/adenosquamous cell type
Mucinous/signet ring cell
Clear cell type
Undifferentiated type
Lymphoepithelial type
Others


담관형 간내 담관암인지 큰 담관형 간내 담관암인지에 따라 기원세포나 암줄기세포가 다를 것으로 추정된다. 최근 연구에 따르면 담관에는 간세포와 담관 세포 모두로 분화할 수 있는 간 줄기/전구 세포(hepatic stem/progenitor cell)와 간세포, 담관 세포 및 췌도로 분화할 수 있는 담관 줄기/전구 세포(biliary tree stem/progenitor cell)의 두 종류의 줄기세포가 있다. 간 줄기/전구 세포들은 주로 담즙 배액 경로의 가장 주변부에 해당하는 헤링 관(canal of Hering)이 니치(niche)로 추정되며 담관 줄기/전구 세포의 니치는 큰 담관 주변에 분포하는 담관 주위선(peribiliary gland)으로 추정된다. ${ }^{30}$ 간내 담관암은 간 줄기/전구 세포 계통이나 담관 줄기/전구 세포 계통에서 모두 발생할 수 있으나 특히 간 줄기/전구 세포 니치는 작은 담관 주위에 질환을 발생시켜 간내 담관암 중 작은 담관형 간내담관암이나 HCC-담관암 혼합형, CK-19 양성 HCC의 발생에 관여하는 것으로 여겨지는 반면, 담관 줄기/전구 세포 니치는 큰 담관 및 간외 담관 주위에서 존재하여 큰 담관형 간내 담관암이나 간문부 담관암 및 원위부담관암의 발생에 관여하는 것으로 생각된다. ${ }^{33-35}$

\section{4. 치료}

간내담도암은 외과적 절제가 유일한 근치적 치료법이나 병의 초기에 증상이 없어 수술이 불가능한 상태로 진단되는 경우가 매우 흔하다. 진단 시 10-45\%의 환자에서 절제 수술이 가능하다고 보고되고 있으며 절제를 한 경우도 수술 후 평균무병생존기간은 12-36개월로 재발이 흔하며 예후가 불량하다. ${ }^{36}$ 그러나 R0 완전 절제가 된 경우 평균 생존기간이 80 개월 이상으로 보고된 코호트 연구 ${ }^{34}$ 도 있어 올바른 간내 담관암의 병기 결정 및 다학제간 접근을 통한 적절한 치료법의 결정은 필수적이다. 수술적 치료를 시행하는 경우 항암화학 요법 및 방사선 요법은 수술 전 또는 수술 후 보조요법으로 사용될 수 있으며, 수술이 불가능한 국소 진행형의 담도암이나 전이성 담도암의 경우 전신요법을 시행할 수 있다. 그러나 전통적 항암 화학요법제의 효과는 다소 비관적이며 최근에는 분자생물학적 특성을 이용한 치료법으로써, 담관암에서 흔히 발견되는 유전자 변이를 이용한 표적치료제 등을 시도하고 있다. ${ }^{37,38}$

\section{1) 병기 결정}

외과적 절제술은 유일하게 치료 가능한 치료법으로 수술 후
5년 전체 생존율은 $15 \%$ 에서 $40 \%$ 이며 ${ }^{39}$ 수술 후 재발은 $2 / 3$ 환자에서 관찰된다. 그러므로 수술 전 올바른 병기 결정은 적절한 치료의 결정에 매우 중요한 과정이다. 미국 암협회의 AJCC 병기분류는 간내 담관암에 대한 병기 기준으로 HCC를 포함한 간의 원발성 종양들과 동일한 병기 기준을 사용하였던 과거와 달리 2010년 발표된 7판부터 간내 담관암에 대한 독립된 병기 기준을 제시하였다. ${ }^{40}$ 최근 발표된 AJCC 8판은 7판의 첫 번째 수정판으로 $\mathrm{T}$ 스테이지에 특히 많은 변화가 있다(Table 2). ${ }^{41}$ 먼저, 종양 크기, 즉 $5 \mathrm{~cm}$ 이상의 큰 종양이 독립적 예후인자임을 반영하여 $\mathrm{T} 1$ 카테고리를 $\mathrm{Tla}$ (종양절단면 $5 \mathrm{~cm}$ 이하)와 $\mathrm{T} 1 \mathrm{~b}$ (종양절단면 $5 \mathrm{~cm}$ 초과)로 세분화하였다. 또한 혈관 침범 여부와 다발성 종양은 여러 연구에서 비슷한 예후효과를 보임을 반영하여 7판에서 $\mathrm{T} 2 \mathrm{a}$ 로 분류되었던 '혈관 침범이 있는 단일 종양'과 $\mathrm{T} 2 \mathrm{~b}$ 로 분류되었던 '혈관 침범이 있거나 없는 다발 종양'을 동일한 T2 카테고리로 결합하였다. 7판의 T4에 해당하는 담관 주위 침범 여부의 예후 효과를 입증할 만한 데이터 부족으로 8 판에서는 $\mathrm{T} 4$ 기준으로 담관 주위 침범 대신 간외 장기의 직접적 침범으로 대체하였다. 7판에서 국소 림프절 전이가 있는 간내 담관암은 IVa기로 분류되었으나 수술 시리즈에서 최대 $1 / 3$ 의 환자에서 국소 임파절 전이가 있다는 자료 등을 근거로 8 판의 경우, 국소 림프절 전이는 IVa에서 $\mathrm{IIIb}$ 로 하향 조정되었으나 전체적으로 $\mathrm{N}$ 스테이지의 정의에 큰 변화는 없다. ${ }^{42}$

간내 담관암 종에 대한 AJCC 병기 8판의 검증 연구들에 따르면 새로 발표된 8 판은 환자의 전체 생존을 계층화하는 데 7판과 유사하거나 더 우수한 것으로 보인다. ${ }^{43-45}$ 그러나 치료 목적의 간 절제술을 받은 환자의 다기관 코호트 분석을 통해 AJCC 8판을 평가한 Spolverato 등 ${ }^{44}$ 의 연구에 따르면 내장 복막 침윤으로 정의되는 8 판의 $\mathrm{T} 3$ 종양의 5 년 전체 생존율이 역설적으로 $\mathrm{T} 1 \mathrm{~b}$ 및 $\mathrm{T} 2$ 종양을 가진 환자의 5 년 전체 생존율을 능가하는 결과를 보였다. 또한, Kang 등 ${ }^{45}$ 의 연구에서도 AJCC 8 판 병기 $\mathrm{T} 2$ 및 $\mathrm{T} 3$ 에 해당하며 림프절 전이가 없는 환자의 종양의 평균 전체 생존율은 각각 25 개월 및 27 개월이며, $\mathrm{T} 2$ 및 $\mathrm{T} 3$ 종양으로의 평균 재발 시간은 각각 14 개월 및 15 개월로 $\mathrm{T} 2$ 와 $\mathrm{T} 3$ 간의 의미 있는 차이가 없었다. Kang 등 ${ }^{45}$ 의 연구와 Spolverato 등 ${ }^{44}$ 의 연구는 8 판 T2, T3 범주가 환자의 예후 및 종양 생물학을 정확하게 반영하지 않음을 시사한다. 실제로 $\mathrm{T} 2$ 에 해당하는 다발성 간종괴는 담관암의 간내 전이와 감별이 모호하여 많은 전문가 합의 그룹에 의해 수술에 대한 금기 사항으로 간주된다. 또한 간내 담관암으로 진단된 162 명의 
Table 2. AJCC staging of intrahepatic cholangiocarcinoma: comparison of 7 th and 8 th editions

\begin{tabular}{|c|c|c|}
\hline & 7th edition & 8th edition \\
\hline \multirow[t]{4}{*}{ T category } & T1: solitary tumor without vascular invasion & $\begin{array}{l}\text { T1a: solitary tumor } \mathrm{i} \leq 5 \mathrm{~cm} \text { without vascular invasion } \\
\text { T1b: solitary tumor }>5 \mathrm{~cm} \text { without vascular invasion }\end{array}$ \\
\hline & T2a: solitary tumor with vascular invasion & $\begin{array}{l}\text { T2: solitary tumor with intrahepatic vascular invasion or multiple } \\
\text { tumors, with or without vascular invasion }\end{array}$ \\
\hline & $\begin{array}{l}\text { T3: tumor perforating the visceral peritoneum or involving local } \\
\text { hepatic structures by direct invasion }\end{array}$ & T3: tumor perforating the visceral peritoneum \\
\hline & T4: tumor with periductal invasion & $\begin{array}{l}\text { T4: tumor involving local extrahepatic structures by direct } \\
\text { invasion }\end{array}$ \\
\hline \multirow[t]{2}{*}{ N category } & N0: no regional lymph node metastasis & N0: no regional lymph node metastasis \\
\hline & N1: regional lymph node metastasis present & N1: regional lymph node metastasis present \\
\hline \multirow[t]{5}{*}{ TNM stage } & I:T1 NO MO & $\begin{array}{l}\text { IA: T1a NO MO } \\
\text { IB: T1b NO MO }\end{array}$ \\
\hline & II: T2 NO M0 & $\|: T 2$ NO MO \\
\hline & III: T3 NO M0 & $\begin{array}{l}\text { IIIA: T3 N0 M0 } \\
\text { III: T4 and/or N1, M0 }\end{array}$ \\
\hline & IVA: T4 N0 M0/any T, N1, M0 & IV: any $T$, any $N, M 1$ \\
\hline & IVB: any T, any N, M1 & \\
\hline
\end{tabular}

환자를 대상으로 한 시리즈 연구에서 다발성 간내 종괴를 가진 환자와 간외 전이를 보인 환자가 비슷한 생존율을 보인 연구 결과 ${ }^{46}$ 도 발표되어 향후 병기 결정 매뉴얼의 개선에 지속적인 노력이 필요하다.

\section{2) 국소 진행성 또는 전이성 간내 담관암의 치료}

\section{(1) 전신 화학항암요법}

전신항암요법의 치료 효과에 대한 연구자료는 대부분 간내 담관암, 간외 담관암, 담낭암 등의 암종이 혼합되어 있어 전신 항암요법의 치료 효과를 간내 담관암만 국한하여 연구한 자료는 부족하다. 진행성 담관암에서 gemcitabine 단독 사용과 cisplatin, gemcitabine 병합요법을 비교한 ABC-02 3상 연구에서 cisplatin, gemcitabine 병합요법은 평균 전체 생존기간 및(11.7 vs. 8.1 months, $\mathrm{p}<0.001$ ), 평균 무진행 생존기간(8 vs. 5 months, $\mathrm{p}<0.001)$ 이 gemcitabin 단독 사용에 비해 의미 있는 결과를 보여 진행성 담관암의 표준 1 차 치료로 현재까지 사용되고 있다. ${ }^{47}$ 유사한 디자인으로 시행된 일본 그룹의 연구인 BT 22 연구도 이를 뒷받침하고 있다. ${ }^{48}$ 그 외 GEMOX, oxaliplatin/5-FU/ leucovorin, capecitabine/oxaliplatin, gemcitabine/albumin-bound paclitaxel, gemcitabine/cetuximab 및 gemcitabine/oxaliplatin/ 5-FU 등 gemcitabine에 근간한 다양한 약제의 병합요법이나
5-FU를 근간으로 하는 약제의 병합요법에 대한 2상 임상 연구들이 진행되고 있으며 panitumumab/gemcitabine/ irinotecan의 제 2 상 치료 연구도 비교적 긍정적인 효과를 보고하고 있다. ${ }^{49-54}$

1 차 치료에 실패한 경우 2 차 치료약제는 아직까지 정립되어 있지 않다. 사용한 1 차 치료제와 다른 작용기전을 가진 약제를 선택하는 것이 원칙이나 2차 치료약제 선택뿐 아니라 2차 치료의 효과에 대해서도 충분한 보고가 부족한 실정이다. ABC-06 연구는 무작위 3상 연구로 gemcitabine, cisplatin 1차 치료제에 실패한 담관암 환자에서 2 차 치료제로 modified FOLFOX (oxaliplatin, leucovorin, fluorouracil) 투여와 보존적 치료만 시행한 군을 비교하는 연구이다. 20 여 개의 기관 참여하에 2018년까지 162명의 담관암 환자 모집 목표치가 충족되어 현재 진행 중이다. 2019년 ASCO 미팅에서 발표된 중간 결과에 따르면 비록 평균 생존기간은 5.3 개월 vs. 6.2개월 $(\mathrm{HR}=0.69 ; \mathrm{p}=0.031)$ 로 뚜렷한 차이는 보이지 않으나 6 개월 생존율 $50.6 \%$ vs $35.5 \%$, 1 년 생존율 $25.9 \%$ vs. $11.4 \%$ 로 유의미한 결과를 보이며 세부 그룹인 간내 담관암 환자에서도 유사한 결과를 보여 향후 발표될 최종 결과가 주목된다.

(2) 표적 치료제

담관암의 흔한 유전적 변이로 KRAS, TP53, CDKN2B, 
ARID1A, IDH1/2, FGFR 융합, BAP1 등이 보고되고 있다. 간내 담관암은 간외 담관암과 해부학적 발생 위치뿐 아니라 분자 생물학적 특징도 차이를 보여 간외 담관암이 KARAS (28\%), TP53 (18\%) 등의 돌연변이가 흔히 관찰되는 반면 간내 담관암의 경우 KARAS, TP53 돌연변이보다는 FGFR 접합 재배열이나 IDH-1 -2 돌연변이등의 유전자 변형이 흔히 보고되어 이들을 이용한 VEGF 억제제, IDH 억제제, FGFR 억제제 등의 표적 치료제의 효과가 조사되고 있다. 그러나 현재까지 진행된 결과로는 타장기에서의 표적치료제의 활용과 달리 담관암에서 표적 치료제의 효과에 대한 연구는 만족스럽지 않다. ${ }^{37,38}$

(1) 표피 성장 인자 수용체(epidermal growth factor receptor, EGFR) 억제제 및 혈관내피 성장인자 수용체(vascular endothelial growth factor receptor, VGFR) 억제제

EGFR나 VGFR 등의 표피 성장 인자 수용체 패밀리는 세포주기, 세포 이동, 혈관신생 등에 중요한 역할을 한다. 간내 담관암의 38-100\%에서 EGFR 경로의 돌연변이가 발견되어 ${ }^{55}$ 이를 이용한 표적 치료제 개발 연구들이 시행되었으나 현재까지 희망적 결과는 보고되지 않고 있다. 대표적 EGFR 억제제인 erlotinib과 gemcitabine, oxaliplatin (GEMOX)의 치료 효과에 대한 무작위 2 상 연구가 진행되었으나 erlotinib의 의미 있는 효과는 관찰되지 않았다. ${ }^{56}$ 혈관신생 표적 치료로 혈관내피 성장 인자 수용체(VGFR) 억제제인 bevacizumab, sunitinib, vandetanib 등에 대한 연구도 진행되었으나 현재까지 의미 있는 결과는 보고되고 있지 않다. ${ }^{57-59}$

(2) IDH1/IDH2 (isocitrate dehydrogenase 1/isocitrate dehydrogenase 2)

간내 담관암의 $15-20 \%$ 에서 발견되는 ${ }^{60} \mathrm{IDH}$ 돌연변이를 이용하여 IDH 억제제인 AG-120 (ivosidenib)을 투여한 1차 임상 연구에서 6개월 무진행율은 40.1\% (28.4-51.6), 12 개월 무진행율은 $21.8 \%$ (12.3-33.0), 평균 생존기간 13.8 개월(95\% CI 11.1-29.3)로 희망적인 결과를 보였다. 현재 IDH1 돌연변이를 보이는 진행성 담관암에 대해 ivosidenib과 플라시보간 다국적 무작위 3상 임상 연구가 목표 모집 환자 등록이 종료된 후 진행되고 있어 결과가 주목된다.

(3) FGFR-2 경로

간내 담관암은 암세포 연관 섬유아세포 기원의 풍부한
섬유질 기질이 특징인 종양으로 실제 간내 담관암 환자의 $11-45 \%$ 에서 섬유아세포 성장 인자 수용체(FGFR) 융합이 발견된다. 융합이 있는 경우 좋은 예후가 보고됨에 따라 BJG398 (infigratinib), INCB54828 (pemigastinib), BAY1163877 (Bayer), TAS -120 (Taiho) 등을 이용한 FGFR 융합 표적 치료 임상 연구가 진행되고 있다. BJG398 (infigratinib)의 경우 이전 항암치료에 실패하였고 FGFR 융합이 있는 환자를 대상으로 시행한 2 상 연구에 따르면 전체 반응률 $18.8 \%$, 질병 통제율 $83.3 \%$, 평균 무진행 기간 5.8개월( $95 \%$ CI 4.3-7.6개월)로 비교적 희망적인 결과를 보고하였다. ${ }^{61}$ 경구 복용 가능한 강력한 FGFR 억제제인 derazantinib (ARQ 087)을 이용한 2상 임상 연구에서 전체 반응률 $20.7 \%$, 질병 통제율 $82.7 \%$, 평균 무진행 기간 5.7 개월( $95 \%$ CI 4.04-9.2개월)로 이전의 약제와 유사한 결과를 보고하고 있다. ${ }^{6}$ 그 외 다른 FGFR-2에 대한 연구들이 활발히 진행되고 있다.

\section{결 론}

간내 담관암은 예후가 매우 나쁜 암종이다. 완전한 종양의 절제가 유일한 근치적 치료법이지만 불행히도 소수의 환자에서만 기능하다. 많은 환자는 수술적 제거가 불가능한 단계에서 진단되므로 조기 진단을 통해 절제 가능한 사례 수를 늘리는 방법을 찾는 것은 주요 과제 중 하나이다. 다학제간 접근을 통한 적절한 치료법의 선택은 환자의 예후 결정에 중요하다. 그러나 전통적 항암 화학요법제의 효과는 다소 비관적이며 최근 시도되고 있는 분자생물학적 특성을 이용한 최신의 치료법도 아직 그 효과가 검증되지 않았다. 향후 간내 담관암의 치료성적 개선을 위해서는 다기관 협력하에 체계화된 연구를 통한 치료 효과의 분석이 필요하며 이를 위해서는 국제적 전향적 임상 시험에 참여하는 것이 도움이 된다. 또한 담관암에서의 유전자 발현 프로파일 및 돌연변이에 대한 발전된 연구의 축척으로 새로운 치료 표적 및 치료제의 선택이 가능해지길 기대한다.

\section{요 약}

담관암은 병변의 해부학적 위치에 따라 간내 담관암과 간외 담관암으로 분류하며 간외 담관암은 다시 간문주변부 담관암과 
원위부 담관암으로 분류한다. 간외 담관암의 발병률은 수십 년 동안 정체되어 있으나 간내 담관암은 전 세계적으로 꾸준히 증가하고 있으며 예후가 극히 나빠 많은 관심이 필요하다. 간내 담관암은 고식적인 해부학적 위치에 따른 분류뿐 아니라 성장 패턴, 조직 학적 소견, 종양 유래 세포에 기반한 다양한 분류 시스템이 제안되어 있으나 아직 합의가 이루어지지 않고 있다. 완전한 종양 절제술이 유일한 치료법이다. 그러나 수술 후 5년 동안의 전체 생존율은 $15-40 \%$ 이며 수술 후 재발하는 환자는 $2 / 3$ 에 달한다. 따라서 수술 전 올바른 병기 결정 및 다학제적 접근을 통한 적절한 치료 방법의 선택은 환자의 예후를 결정하는 중요한 과정이다. 다양한 전신 요법은 수술이 불가능한 국소 진행성 담도암 또는 전이성 담도암에 사용될 수 있으나 전통적인 항암 화학 요법제의 효과는 다소 비관적이다. 최근 분자 생물학적 특성을 이용한 치료가 시도되고 있으나 그 효과는 아직 입증되지 않아 조기 진단을 통해 절제 가능한 사례의 수를 늘리는 방법을 찾는 것이 주요 과제 중 하나로 고려되고 있다. 그러나 향후 담관암의 유전자 발현 프로파일 및 돌연변이에 대한 고도의 연구 결과로 새로운 치료 표적 및 치료제가 선정되어 예후가 개선되기를 기대한다.

국문 색인: 간내 담관암, 분류, 병기, 내과적 치료

\section{Conflicts of Interest}

The author has no conflicts to disclose.

\section{REFERENCES}

1. Rizvi S, Gores GJ. Pathogenesis, diagnosis, and management of cholangiocarcinoma. Gastroenterology 2013;145:1215-1229.

2. Patel T. Worldwide trends in mortality from biliary tract malignancies. BMC Cancer 2002;2:10.

3. Khan SA, Taylor-Robinson SD, Toledano MB, Beck A, Elliott P, Thomas $H C$. Changing international trends in mortality rates for liver, biliary and pancreatic tumours. J Hepatol 2002;37:806-813.

4. Khan SA, Toledano MB, Taylor-Robinson SD. Epidemiology, risk factors, and pathogenesis of cholangiocarcinoma. HPB (Oxford) 2008; 10:77-82.

5. Shaib YH, Davila JA, McGlynn K, El-Serag HB. Rising incidence of intrahepatic cholangiocarcinoma in the United States: a true increase? J Hepatol 2004;40:472-477.

6. Saha SK, Zhu AX, Fuchs CS, Brooks GA. Forty-year trends in cholangiocarcinoma incidence in the U.S.: intrahepatic disease on the rise. Oncologist 2016;21:594-599.
7. Shaib Y, El-Serag HB. The epidemiology of cholangiocarcinoma. Semin Liver Dis 2004;24:115-125.

8. West J, Wood H, Logan RF, Quinn M, Aithal GP. Trends in the incidence of primary liver and biliary tract cancers in England and Wales 1971-2001. Br J Cancer 2006;94:1751-1758.

9. Bergquist $A$, von Seth E. Epidemiology of cholangiocarcinoma. Best Pract Res Clin Gastroenterol 2015;29:221-232.

10. Rizvi S, Khan SA, Hallemeier CL, Kelley RK, Gores GJ. Cholangiocarcinoma - evolving concepts and therapeutic strategies. Nat Rev Clin Oncol 2018;15:95-111.

11. Jarnagin WR. Cholangiocarcinoma of the extrahepatic bile ducts. Semin Surg Oncol 2000;19:156-176.

12. Su CH, Shyr YM, Lui WY, P'Eng FK. Hepatolithiasis associated with cholangiocarcinoma. Br J Surg 1997;84:969-973.

13. Chapman MH, Webster GJ, Bannoo S, Johnson GJ, Wittmann J, Pereira SP. Cholangiocarcinoma and dominant strictures in patients with primary sclerosing cholangitis: a 25-year single-centre experience. Eur J Gastroenterol Hepatol 2012;24:1051-1058.

14. Lipsett PA, Pitt HA, Colombani PM, Boitnott JK, Cameron JL. Choledochal cyst disease. A changing pattern of presentation. Ann Surg 1994:220:644-652

15. Watanapa P, Watanapa WB. Liver fluke-associated cholangiocarcinoma. Br J Surg 2002;89:962-970.

16. Donato F, Gelatti U, Tagger A, et al. Intrahepatic cholangiocarcinoma and hepatitis $C$ and $B$ virus infection, alcohol intake, and hepatolithiasis: a case-control study in Italy. Cancer Causes Control 2001;12:959964.

17. Kobayashi M, Ikeda K, Saitoh S, et al. Incidence of primary cholangiocellular carcinoma of the liver in Japanese patients with hepatitis C virus-related cirrhosis. Cancer 2000;88:2471-2477.

18. Shaib YH, El-Serag HB, Davila JA, Morgan R, McGlynn KA. Risk factors of intrahepatic cholangiocarcinoma in the United States: a case-control study. Gastroenterology 2005;128:620-626.

19. Sorensen HT, Friis $S$, Olsen $J H$, et al. Risk of liver and other types of cancer in patients with cirrhosis: a nationwide cohort study in Denmark. Hepatology 1998;28:921-925.

20. Welzel TM, Graubard BI, Zeuzem S, El-Serag HB, Davila JA, McGlynn $\mathrm{KA}$. Metabolic syndrome increases the risk of primary liver cancer in the United States: a study in the SEER-Medicare database. Hepatology 2011;54:463-471.

21. Li JS, Han TJ, Jing N, et al. Obesity and the risk of cholangiocarcinoma: a meta-analysis. Tumour Biol 2014;35:6831-6838.

22. Petrick JL, Thistle JE, Zeleniuch-Jacquotte A, et al. Body mass index, diabetes and intrahepatic cholangiocarcinoma risk: the liver cancer pooling project and meta-analysis. Am J Gastroenterol 2018;113:1494-1505.

23. Kendall T, Verheij J, Gaudio E, et al. Anatomical, histomorphological and molecular classification of cholangiocarcinoma. Liver Int 2019;39(Suppl 1):7-18. 
24. Banales JM, Cardinale V, Carpino G, et al. Expert consensus document: cholangiocarcinoma: current knowledge and future perspectives consensus statement from the European Network for the Study of Cholangiocarcinoma (ENS-CCA). Nat Rev Gastroenterol Hepatol 2016;13:261-280.

25. Yamasaki S. Intrahepatic cholangiocarcinoma: macroscopic type and stage classification. J Hepatobiliary Pancreat Surg 2003;10:288-291.

26. Blechacz B, Komuta M, Roskams T, Gores GJ. Clinical diagnosis and staging of cholangiocarcinoma. Nat Rev Gastroenterol Hepatol 2011;8:512-522.

27. Kim H, Lim JH, Jang KT, et al. Morphology of intraductal papillary neoplasm of the bile ducts: radiologic-pathologic correlation. Abdom Imaging 2011;36:438-446.

28. Sakamoto $E$, Nimura $Y$, Hayakawa $N$, et al. The pattern of infiltration at the proximal border of hilar bile duct carcinoma: a histologic analysis of 62 resected cases. Ann Surg 1998;227:405-411.

29. Nakanuma Y, Sato Y, Harada K, Sasaki M, Xu J, Ikeda H. Pathological classification of intrahepatic cholangiocarcinoma based on a new concept. World J Hepatol 2010;2:419-427.

30. Liau JY, Tsai JH, Yuan RH, Chang CN, Lee HJ, Jeng YM. Morphological subclassification of intrahepatic cholangiocarcinoma: etiological, clinicopathological, and molecular features. Mod Pathol 2014;27:11631173.

31. Komuta M, Govaere O, Vandecaveye V, et al. Histological diversity in cholangiocellular carcinoma reflects the different cholangiocyte phenotypes. Hepatology 2012;55:1876-1888.

32. Visvader JE. Cells of origin in cancer. Nature 2011;469:314-322.

33. Carpino G, Renzi A, Franchitto A, et al. Stem/progenitor cell niches involved in hepatic and biliary regeneration. Stem Cells Int 2016;2016:3658013.

34. Lanzoni G, Cardinale V, Carpino G. The hepatic, biliary, and pancreatic network of stem/progenitor cell niches in humans: a new reference frame for disease and regeneration. Hepatology 2016;64:277-286.

35. Carpino G, Cardinale V, Onori $P$, et al. Biliary tree stem/progenitor cells in glands of extrahepatic and intraheptic bile ducts: an anatomical in situ study yielding evidence of maturational lineages. J Anat 2012;220:186-199.

36. Konstadoulakis MM, Roayaie S, Gomatos IP, et al. Fifteen-year, single-center experience with the surgical management of intrahepatic cholangiocarcinoma: operative results and long-term outcome. Surgery 2008;143:366-374.

37. Adeva J, Sangro B, Salati M, et al. Medical treatment for cholangiocarcinoma. Liver Int 2019;39(Suppl 1):123-142.

38. Kelley RK, Bridgewater J, Gores GJ, Zhu AX. Systemic therapies for intrahepatic cholangiocarcinoma. J Hepatol 2020;72:353-363.

39. DeOliveira ML, Cunningham SC, Cameron JL, et al. Cholangiocarcinoma: thirty-one-year experience with 564 patients at a single institution. Ann Surg 2007;245:755-762.

40. Edge SB, American Joint Committee on Cancer. AJCC cancer staging handbook. 7th ed. pXIV, 648. New York, Springer, 2010.

41. Amin MB, American Joint Committee on Cancer, American Cancer Society. AJCC cancer staging handbook. 8th ed. pXVII, 1024. Chicago (IL), American Joint Committee on Cancer, Springer, 2017.

42. Lee AJ, Chun YS. Intrahepatic cholangiocarcinoma: the AJCC/UICC 8th edition updates. Chin Clin Oncol 2018;7:52.

43. Kim Y, Moris DP, Zhang XF, et al. Evaluation of the 8th edition American Joint Commission on Cancer (AJCC) staging system for patients with intrahepatic cholangiocarcinoma: a surveillance, epidemiology, and end results (SEER) analysis. J Surg Oncol 2017;116:643-650.

44. Spolverato $G$, Bagante $F$, Weiss $M$, et al. Comparative performances of the 7th and the 8th editions of the American Joint Committee on Cancer staging systems for intrahepatic cholangiocarcinoma. J Surg Oncol 2017;115:696-703.

45. Kang SH, Hwang S, Lee YJ, et al. Prognostic comparison of the 7th and 8th editions of the American Joint Committee on Cancer staging system for intrahepatic cholangiocarcinoma. J Hepatobiliary Pancreat Sci 2018;25:240-248.

46. Lamarca A, Santos-Laso A, Utpatel K, et al. Liver metastases of intrahepatic cholangiocarcinoma: implications for a potential new staging system. Hepatology 2020 Oct 18. [Epub ahead of print]

47. Valle J, Wasan H, Palmer DH, et al. Cisplatin plus gemcitabine versus gemcitabine for biliary tract cancer. N Engl J Med 2010;362:12731281.

48. Okusaka T, Nakachi K, Fukutomi A, et al. Gemcitabine alone or in combination with cisplatin in patients with biliary tract cancer: a comparative multicentre study in Japan. Br J Cancer 2010;103:469-474.

49. André $T$, Reyes-Vidal JM, Fartoux L, et al. Gemcitabine and oxaliplatin in advanced biliary tract carcinoma: a phase II study. Br J Cancer 2008;99:862-867.

50. Sahai V, Catalano PJ, Zalupski MM, et al. Nab-paclitaxel and gemcitabine as first-line treatment of advanced or metastatic cholangiocarcinoma: a phase 2 clinical trial. JAMA Oncol 2018;4:1707-1712.

51. Nehls O, Klump B, Arkenau HT, et al. Oxaliplatin, fluorouracil and leucovorin for advanced biliary system adenocarcinomas: a prospective phase II trial. Br J Cancer 2002;87:702-704.

52. Nehls $\mathrm{O}$, Oettle $\mathrm{H}$, Hartmann JT, et al. Capecitabine plus oxaliplatin as first-line treatment in patients with advanced biliary system adenocarcinoma: a prospective multicentre phase II trial. Br J Cancer 2008;98:309-315.

53. Borbath I, Ceratti A, Verslype $C$, et al. Combination of gemcitabine and cetuximab in patients with advanced cholangiocarcinoma: a phase II study of the Belgian Group of Digestive Oncology. Ann Oncol 2013;24:2824-2829.

54. Wagner AD, Buechner-Steudel P, Moehler M, et al. Gemcitabine, oxaliplatin and 5-FU in advanced bile duct and gallbladder carcinoma: two parallel, multicentre phase-II trials. Br J Cancer 2009;101:18461852.

55. Pignochino Y, Sarotto I, Peraldo-Neia C, et al. Targeting EGFR/HER2 
pathways enhances the antiproliferative effect of gemcitabine in biliary tract and gallbladder carcinomas. BMC Cancer 2010;10:631.

56. Gruenberger B, Schueller J, Heubrandtner U, et al. Cetuximab, gemcitabine, and oxaliplatin in patients with unresectable advanced or metastatic biliary tract cancer: a phase 2 study. Lancet Oncol 2010;11:1142-1148.

57. Zhu AX, Meyerhardt JA, Blaszkowsky LS, et al. Efficacy and safety of gemcitabine, oxaliplatin, and bevacizumab in advanced biliary-tract cancers and correlation of changes in 18-fluorodeoxyglucose PET with clinical outcome: a phase 2 study. Lancet Oncol 2010;11:48-54.

58. Lubner SJ, Mahoney MR, Kolesar JL, et al. Report of a multicenter phase II trial testing a combination of biweekly bevacizumab and daily erlotinib in patients with unresectable biliary cancer: a phase II
Consortium study. J Clin Oncol 2010;28:3491-3497.

59. Iyer RV, Pokuri VK, Groman A, et al. A multicenter phase II study of gemcitabine, capecitabine, and bevacizumab for locally advanced or metastatic biliary tract cancer. Am J Clin Oncol 2018;41:649-655.

60. Borger DR, Zhu AX. IDH mutations: new genetic signatures in cholangiocarcinoma and therapeutic implications. Expert Rev Anticancer Ther 2012;12:543-546.

61. Javle M, Lowery M, Shroff RT, et al. Phase II study of BGJ398 in patients with FGFR-altered advanced cholangiocarcinoma. J Clin Oncol 2018;36:276-282.

62. Mazzaferro V, El-Rayes BF, Droz Dit Busset M, et al. Derazantinib (ARQ 087) in advanced or inoperable FGFR2 gene fusion-positive intrahepatic cholangiocarcinoma. Br J Cancer 2019;120:165-171. 